Vol. 1 No. 3 November 2021, e-ISSN : 2797-0140 | p-ISSN : 2797-0590

\title{
PENGGUNAAN BAHAN AJAR BERBASIS AUDIO VISUAL UNTUK MENINGKATKAN HASIL BELAJAR SISWA KELAS VIII-J PADA MATA PELAJARAN PABP MATERI SHALAT SUNAT DI SMPN 1 TASIKMALAYA
}

\author{
SRI SABTUTI \\ SMPN 1 Tasikmalaya Provinsi Jawa Barat \\ Email : srisabtuti@gmail.com
}

\begin{abstract}
ABSTRAK
Penelitian ini bertujuan untuk mendeskripsikan penggunaan bahan ajar berbasis audio visual untuk meningkatkan hasil belajar siswa kelas VIII-J SMPN 1 Tasikmalaya dalam mempelajari Pendidikan Agama \& Budi Pekerti (PABP) materi Shalat Sunah tahun pelajaran 2021/2022. Penelitian ini merupakan Penelitian Tindakan Kelas (PTK) yang terdiri atas 2 (dua) siklus. Setiap siklus terdiri atas tahap perencanaan, pelaksanaan tindakan, pengamatan (observasi) dan refleksi. Subyek penelitian ini adalah seluruh siswa VIII-J SMPN 1 Tasikmalaya yang berjumlah 34 siswa. Teknik pengumpulan data meliputi observasi, wawancara, tes, dan dokumen. Teknik analisis data menggunakan analisis deskriptif kualitatif. Hasil penelitian menunjukkan bahwa rata-rata nilai hasil belajar siswa pada siklus I sebesar 76,37 dengan ketuntasan klasikal sebesar 64,76\%, meningkat menjadi 87,53 dengan ketuntasan klasikal 91,17\% pada siklus II. Penggunaan bahan ajar berbasis audio visual dapat meningkatkan hasil belajar siswa VIII-J SMPN 1 Tasikmalaya pada mata pelajaran PABP Materi Shalat Sunah semester ganjil tahun pelajaran 2021/2022.
\end{abstract}

Kata Kunci: Bahan ajar, audio visual, hasil belajar

\section{ABSTRACT}

This study aims to describe the use of audio-visual-based teaching materials to improve student learning outcomes in grades VIII-J of SMPN 1 Tasikmalaya in studying Religious Education \& Morals (PABP) for Sunna Prayer material for the 2021/2022 school year. This research is a Classroom Action Research (CAR) which consists of 2 (two) cycles. Each cycle consists of stages of planning, implementing actions, observing and reflecting. The subjects of this study were all students VIII-J of SMPN 1 Tasikmalaya, totaling 34 students. Data collection techniques include observation, interviews, tests, and documents. The data analysis technique used descriptive qualitative analysis. The results showed that the average value of student learning outcomes in the first cycle was 76.37 with classical completeness of $64.76 \%$, increased to 87.53 with $91.17 \%$ classical completeness in the second cycle. The use of audio-visual-based teaching materials can improve the learning outcomes of VIII-J students of SMPN 1 Tasikmalaya in the PABP subject for the odd semester Sunna prayer material for the 2021/2022 academic year.

Keywords: Teaching materials, audio visual, learning outcomes

\section{PENDAHULUAN}

Pendidikan merupakan pondasi awal yang paling berpengaruh dalam upaya meningkatkan kualitas kehidupan suatu bangsa. Melalui proses pendidikan, kognitif seseorang akan menjadi luas dan bertambah. Pendidikan dapat menjadi tolak ukur kualitas sumber daya manusia (Asrial, dkk, 2020). UU no 20 tahun 2003 menyatakan bahwa pendidikan merupakan usaha sadar serta terencana dalam mewujudkan suasana belajar aktif sehingga siswa dapat mengembangkan potensi dan kepribadiannya kearah yang lebih baik. Pendidikan dapat menumbuhkan potensi diri secara intelektual dan emosional yang dapat membuat seseorang menjadi lebih baik. Berdasarkan hal tersebut maka dapat dikatakan bahwa pendidikan memiliki peranan penting dalam menyiapkan sumber daya manusia berkualitas. Pada era revolusi industri ini, salah satu yang mempengaruhi dunia pendidikan adalah perkembangan teknologi yang sangat pesat 
Teknologi merupakan salah satu sarana yang dapat memajukan dunia pendidikan. Teknologi dapat digunakan sebagai pemecahan masalah Pendidikan, yang akan memberikan manfaat peningkatan kualitas Pendidikan (Pratama, dkk, 2017). Perkembangan teknologi yang begitu cepat menyebabkan media cetak akan ditinggalkan dan beralih pada teknologi komputer dalam proses pembelajaran.

Dengan kemajuan teknologi sekarang ini, pendidik diharuskan untuk lebih inovatif dalam penyampaian materi pelajaran. Untuk itulah dibutuhkan media pembelajaran yang didukung dengan adanya teknologi pendidikan. Oleh sebab itu dengan tersedianya bahan ajar atau media pembelajaran bisa mewujudkan metode belajar mengajar yang efisien serta efektif dan produktif sehinga diharapkan siswa lebih bersinergi dalam proses pembelajaran. Pendidik juga bisa menciptakan suatu pembelajaran yang modern yang menjadikan siswa lebih aktif dan guru hanya sebagai fasilitator serta tetap bertanggung jawab atas jalannya pembelajaran yang menyenangkan agar kegiatan pembelajaran tidak hanya dilakukan dengan metode ceramah dan hanya berpacu dengan buku siswa atau buku paket saja.

Pada penelitian yang ditulis oleh Hendra Pratama (2016), menyatakan setiap sekolah atau setiap mata pelajaran hendaknya guru memiliki bahan ajar yang disusun sesuai konsep dan teori secara sistematis agar siswa dapat memahami dan mencerna secara maksimal materi pelajaran yang disajikan. Adanya bahan ajar juga mengurangi aktivitas mencatat siswa sehingga mereka lebih mempunyai banyak waktu untuk memahami lebih banyak materi.

Bahan ajar menjadi salah satu kebutuhan dalam pembelajaran yang harus dikembangkan. Bagian penting dalam pelaksanaan proses pembelajaran di sekolah salah satunya adalah bahan ajar. Dalam proses pembelajaran guru dan siswa akan sangat terbantu dengan adanya bahan ajar untuk mempermudah penyampaian materi ajar. Adapun pengertian bahan ajar adalah segala bentuk informasi, baik berupa teks sebagai alat bantu dalam kegiatan pembelajaran dikelas (Andi Prastowo, 2014). Agar suatu bahan ajar memiliki makna dalam membantu proses pembelajaran, seyogyanya para guru memiliki daya kreatifitas yang tinggi dalam menyusun dan mendesain bahan pembelajaran supaya siswa tertarik dengan bahan ajar yang disajikan dan juga mempermudah proses pemahaman siswa yang pada akhirnya akan memberikan efek pada hasil yang diperoleh oleh siswa. Bahan ajar yang berbasis audio visual adalah salah satunya yang bisa dikembangkan oleh guru. Dengan bahan ajar berbasis audio visual ini diharapkan para siswa agar tidak merasa jenuh serta dapat meningkatkan hasil belajar.

Banyak faktor yang menyebabkan kejenuhan dalam belajar termasuk dalam pembelajaran Pendidikan Agama \& Budi Pekerti (PABP), salah satunya adalah faktor ketidaksukaan terhadap materi PABP karena dianggap sulit. Berdasarkan hasil observasi dan wawancara yang telah dilakukan dengan beberapa siswa kelas VIII SMPN 1 Tasikmalaya, diperoleh informasi bahwa diantara faktor kurangnya minat belajar PABP adalah mereka beranggapan bahwa pelajaran PABP pelajaran yang dianggap sulit, monoton, selain itu sumber belajar yang digunakan oleh guru dalam mengajar berupa bahan ajar cetak dan guru masih dominan mengajar dengan metode ceramah dalam pembelajaran.

Berdasarkan beberapa masalah tesebut maka dalam penelitian ini peneliti memilih media pembelajaran microsoft power point untuk merancang bahan ajar dalam bentuk audio visual. Penggunaan media pembelajaran ini sangat berperan penting dalam kegiatan pembelajaran terutama pada siswa belajar PABP. Dengan menggunakan media pembelajaran yang tepat dan bervariasi dapat mengatasi sikap pasif siswa atau kesulitan siswa terutama dalam memahami konsep-konsep abstrak materi PABP akan hilang pada saat pembelajaran. Dengan demikian, ketertarikan untuk belajar akan lebih cepat tertanam secara maksimal dalam diri siswa serta siswa dapat memperoleh pembelajaran yang menyenangkan dengan menggunakan media pembelajaran yang kreatif dan inovatif. Seperti yang dijelaskan oleh (Sukiyasa \& Sukoco, 2013) bahwa supaya pembelajaran lebih menarik, dipahami, dan lebih dapat dimotivasi siswa didik, maka materi pelajaran dibuat visualisasi. Oleh karena itu penulis tertarik untuk melakukan penelitian tindakan kelas Penggunaan Bahan Ajar Berbasis Audio Visual Untuk 
Meningkatkan Hasil Belajar Siswa Kelas VIII-J pada Mata Pelajaran PABP Materi Shalat Sunat di SMPN 1 Tasikmalaya

\section{METODE PENELITIAN}

Metode yang digunakan oleh peneliti dalam penelitian ini adalah Penelitian Tindakan Kelas (PTK). Seperti yang didefinisikan oleh Suyanto (dalam Subyantoro 2007:6) bahwa PTK sebagai tindakan tertentu agar dapat memperbaiki dan atau meningkatkan praktik-praktik pembelajaran di kelas secara profesional. Penelitian ini bertujuan untuk mengetahui penggunaan bahan ajar berbasis audio visual untuk meningkatkan hasil belajar siswa pada mata pelajaran Pendidikan Agama dan Budi Pekerti (PABP) materi shalat sunat di SMPN 1 Tasikmalaya semester 1 tahun pelajaran 2021/2022 dengan subjek penelitian yakni siswa kelas VIII-J berjumlah 34 orang yang terdiri dari 15 putera dan 19 puteri.

Teknik pengumpulan data dalam penelitian ini menggunakan metode observasi, wawancara, tes, dan dokumen. Metode analisis data menggunakan analisis deskriptif kualitatif. Prosedur penelitian tindakan kelas ini setiap siklusnya terdiri atas empat kegiatan yaitu: 1) Perencanaan, sebelum mengadakan penelitian peneliti menyusun rumusan masalah, tujuan dan membuat rencana tindakan, termasuk di dalamnya intrumen penelitian dan perangkat pembelajaran. 2) Tindakan dan pengamatan atau observasi, meliputi tindakan yang dilakukan oleh peneliti sebagai upaya membangun pemahaman konsep peserta didik serta mengamati hasil atau dampak dari penggunaan bahan ajar berbasis audio visual. 3) Refleksi, Tahap refleksi diperlukan untuk mengkaji serangkaian kegiatan yang telah dilakukan sebelumnya. Pengkajian kembali dapat digunakan peneliti untuk mengetahui kegiatan yang telah dicapai dan yang belum dicapai pada saat pelaksanaan tindakan dan observasi. 4) Rencana perbaikan, kegiatan yang dilaksanakan pada tahap perencanaan pada siklus II, berdasarkan refleksi dari siklus I, diperoleh data mengenai kekurangan-kekurangan yang terjadi pada siklus I yang merupakan acuan untuk melaksanakan tindakan perbaikan pada siklus II agar hasil tindakan vang dicapai lebih optimal. Berikut skema bagan per

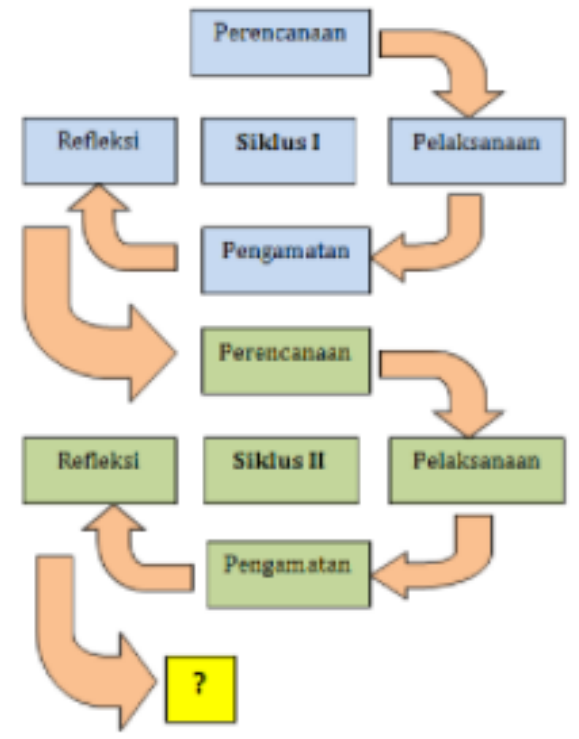

\section{Gambar 1. Skema Bagan Penelitian Tindakan Kelas}

\section{HASIL DAN PEMBAHASAN}

\section{Hasil}

\section{Kondisi Awal}

Sebelum melaksanaan tindakan penelitian, peneliti melakukan ulangan harian kepada peserta didik. Ulangan harian PABP pada pokok bahasan Shalat Sunah Berjamaah dan Munfarid yang dilaksanakan pada hari Kamis 14 Oktober 2021, dimana dilakukan ulangan harian pra tindakan yang bertujuan untuk mengetahui penguasaan peserta didik dalam materi 
Shalat Sunah Berjamaah dan Munfarid yang dijadikan topik pembahasan sebelum penelitian tindakan kelas dilaksanakan. Dimana dalam proses pembelajarannya menggunakan bahan ajar secara konvensional dan belum mendesain pembelajaran menggunakan bahan ajar berbasis audio visual ternyata hasilnya kurang memuaskan.

Dari hasil belajar PABP peserta didik terlihat bahwa hasil belajar peserta didik kelas VIII-J SMPN 1 Tasikmalaya, memperoleh nilai rata-rata 68 atau ketuntasan hanya mencapai $35 \%$ termasuk dalam kategori sangat rendah. Hal tersebut dikarenakan ulangan harian tentang Shalat Sunah Berjamaah dan Munfarid merupakan materi yang banyak pembahasannya serta ada pengelompokkan shalat-shalat sunah yang dikerjakan secara munfarid dan berjamaah, sehingga kalau pembelajarannya masih menggunakan bahan ajar konvensional akan menyulitkan siswa untuk memamahaminya. Hal ini memberikan indikator bahwa proses pembelajaran belum mencapai tujuan yang diharapkan peneliti yang tertuang dalam indikator keberhasilan pembelajaran yaitu mencapai ketuntasan individual yaitu sesuai KKM yang telah ditentukan sekolah (76), sehingga perlu mendesain pembelajaran menggunakan bahan ajar yang berbasiskan media audio visual sehingga hasil belajar peserta didik meningkat.

\section{Siklus I}

Pada tahap ini dilaksanakan kegiatan uji coba menggunakan bahan ajar yang berbasiskan media audio visual, pelaksanaan tindakan siklus I dilaksanakan pada hari Kamis 21 Oktober 2021 (sesuai dengan roster mata pelajaran). Pembelajaran siklus I ini dihadiri oleh 32 siswa dari jumlah 34 siswa kelas VIII_J..

Hasil observasi siklus I menujukkan bahwa jumlah peserta didik yang hadir pada saat proses pembelajaran berlangsung adalah 32 siswa. Peserta didik yang mengamati bahan ajar berbasis audio visual (Power Point) sebanyak 20 siswa, dan selebihnya disebabkan karena peserta didik yang sibuk sendiri, kurangnya peserta didik yang mencatat indikator disebabkan karena peserta didik yang malas menulis dan merasa bosan. Kurangnya peserta didik yang meminta bimbingan disebabkan karena peserta didik merasa takut untuk berbicara, peserta didik belum percaya diri sehingga enggan untuk berbicara pada guru. Kurangnya peserta didik yang aktif disebabkan peserta didik yang takut salah saat mengemukaan pendapatnya, dan juga tidak percaya diri.

Kurangnya peserta didik yang dapat menyimpulkan pelajaran disebabkan karena tidak memperhatikan pelajaran sehingga tidak mereka tidak tahu apa yang harus disimpulkan. Hal ini berarti ketercapaian indikator belum tercapai, sehingga penelitian dilanjutkan pada siklus II.

Tabel 1. Klasifikasi hasil belajar peserta didik setelah mendesain pembelajaran menggunakan bahan ajar berbasis media audio visual (Power Point).

\begin{tabular}{|c|l|c|c|c|}
\hline No & \multicolumn{1}{|c|}{ Nilai } & Kategori & Frekuensi & Persentase \\
\hline 1 & $80-100$ & Sangat baik/Sangat tinggi & 10 & 31 \\
\hline 2 & $70-79$ & Baik/tinggi & 12 & 37,5 \\
\hline 3 & $60-69$ & Sedang & 6 & 19 \\
\hline 4 & $50-59$ & Kurang & 4 & 12,5 \\
\hline 5 & $\leq 49$ & Sangat kurang & 0 & 0 \\
\hline \multicolumn{5}{|c|}{ Jumlah } \\
\hline
\end{tabular}

\section{Siklus II}

Pada tahap pelaksanaan tindakan siklus II berlangsung selama 2 kali pertemuan dengan dilaksanakan pada hari Kamis 28 Oktober 2021 (sesuai dengan roster mata pelajaran). Pada pertemuan ini dihadiri oleh keseluruhan peserta didik yaitu 34 anak.

Hasil observasi siklus II menujukkan bahwa bahwa hampir semua peserta didik beraktivitas sesuai indikator, hasil persentase tingkat observasi sebesar 90\% ini menujukkan bahwa aktivitas peserta didik pada siklus II jika dikategorisasikan berada pada kategori sangat tinggi, aktivitas peserta didik meningkat dari siklus sebelumnya, Hal ini berarti ketercapaian 
indikator sudah tercapai, peserta didik sudah mengerti dan terbiasa menggunakan bahan ajar berbasis audio visual (Power Point) dalam pembelajaran. Sehingga dengan demikian penelitian tidak perlu lagi dilanjutkan pada siklus berikutnya.

Tabel 2. Klasifikasi hasil belajar peserta didik setelah mendesain pembelajaran menggunakan media PowerPoint.

\begin{tabular}{|c|l|c|c|c|}
\hline No & \multicolumn{1}{|c|}{ Nilai } & Kategori & Frekuensi & Persentase \\
\hline 1 & $80-100$ & Sangat baik/Sangat tinggi & 31 & 91 \\
\hline 2 & $70-79$ & Baik/tinggi & 3 & 9 \\
\hline 3 & $60-69$ & Sedang & 0 & 0 \\
\hline 4 & $50-59$ & Kurang & 0 & 0 \\
\hline 5 & $\leq 49$ & Sangat kurang & 0 & 0 \\
\hline \multicolumn{5}{|c|}{ Jumlah } \\
\hline
\end{tabular}

Berikut adalah hasil belajar yang dicapai dari siklus 1 dan siklus 2

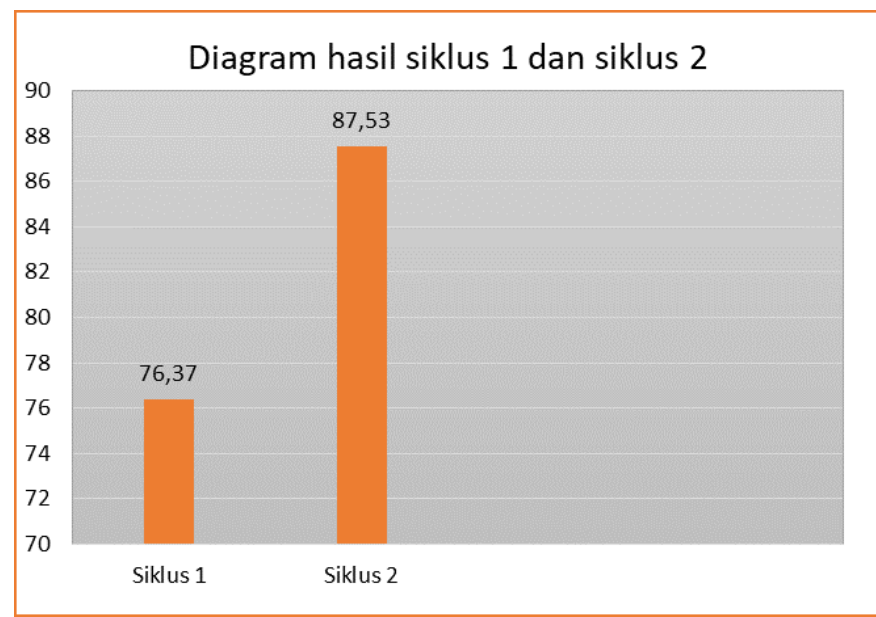

Gambar 2. Diagram hasil belajar siklus 1 dan siklus 2

Berdasarkan gambar diagram analisis hasil belajar siswa di atas, dapat diketahui peningkatan hasil belajar siswa setelah dilakukan tindakan perbaikan dengan penggunaan bahan ajar berbasis audio visual (powerpoint) pada materi Shalat Sunah Nilai rata-rata hasil belajar pada siklus I sebesar 76,37 dengan ketuntasan klasikal 64,76\% meningkat menjadi 87,53 dengan ketuntasan klasikal sebesar 91,17\% pada siklus II. Peningkatan hasil belajar tersebut menunjukkan bahwa target penelitian telah tercapai yaitu siswa yang mendapatkan nilai lebih dari KKM yang ditentukan sekolah yaitu >76 lebih dari 75\% dari seluruh siswa kelas VIII-J.

\section{Pembahasan}

\section{Penilaian kelayakan desain bahan ajar berbasis audio visual (PowerPoint)}

Sebelum dilakukan penilaian kelayakan desain bahan ajar berbasis audio visual (Power Point) terlebih dahulu dilakukan analisis perangkat pembelajaran dan instumen penelitian. Hasil analisis data yang telah dilakukan dapat digunakan untuk melihat sejauh mana baik tidaknya perangkat pembelajaran dan instrument penelitian yang telah dirangcang. Perangkat yang dirangcang dalam hal ini ialah rencana pelaksanaan pembelajaran, lembar kegiatan peserta didik, dan instrument penelitian yang dirangcang dalam hal ini lembar instrument penilaian untuk validator, lembar instrument penilaian oleh peserta didik, dan tes hasil belajar peserta didik. Penilaian perangkat pembelajaran dan instrumen oleh para ahli sebelum menggunakan desain bahan ajar berbasis audio visual (Power Point) terlebih dahulu dinilai kelayakannya berdasarkan pada dua hal, yaitu penilaian dari validator dan data empirik hasil respon peserta didik terhadap pembelajaran menggunakan bahan ajar berbasis media audio visual (Power Point). Penilaian oleh validator diberikan sebelum menggunakan bahan ajar berbasis media 
audio visual dalam pembelajaran peneliti membagikan lembar penilaian kepada validator untuk melihat kelayakan bahan ajar berbasis audio visual, mulai dari aspek audio visual, aspek isi, aspek penyajian, dan aspek menyeluruh.

Dari hasil penelitian menunjukkan bahwa bahan ajar berbasis audio visual sudah layak untuk digunakan di sekolah sebagai bahan ajar tambahan. Sedangkan instrument respon peserta didik diberikan pada akhir pertemuan siklus II. Penilaian oleh peserta didik dilihat dari dua aspek yakni aspek strategi pembelajaran dan aspek tampilan. Dari hasil instrument respon siswa, didapatkan desain bahan ajar berbasis audio visual yang telah digunakan berada pada kategori layak. Ini menunjukkan bahwa bahan ajar tersebut dapat di produksi untuk digunakan dalam skala besar.

\section{Perubahan Aktivitas dan Hasil Belajar Peserta didik}

Berdasarkan hasil analisis kuantitatif dan kualitatif, terlihat bahwa pada dasarnya pelaksanaan pembelajaran peningkatan kualitas hasil belajar PABP pada materi shalat sunah melalui pembelajaran menggunakan desain bahan ajar berbasis media audio visual (Power Point) di kelas VIII-J SMPN 1 Tasikmalaya dapat memberikan perubahan nilai dan perilaku peserta didik dalam belajar. Selain itu, membentuk jiwa peserta didik yang lebih aktif dalam kegiatan pembelajaran. Perubahan tersebut pada kebiasaan peserta didik yang dilakukan sebelum dilaksanakannya pengajaran menggunakan desain bahan ajar berbasis media audio visual (Power Point) yang ketika pembelajaran sedang berlangsung mereka tidak memperhatikan penjelasan guru. Setelah mendesain terlihat ada peningkatan aktivitas dan hasil belajarnya.

Pada siklus I peserta didik masih terlihat bingung dengan tugas mereka di kelas, hal ini dapat disebabkan pembelajaran dengan bahan ajar berbasis media audio visual (Power Point) merupakan hal baru dan belum diterapkan sebelumnya sehingga pencapaian hasil belajar yang dicapai peserta didik belum maksimal. Dengan usaha dan bimbingan yang tekun diharapkan dapat meningkatkan motivasi peserta didik dengan harapan dapat meningkatkan pencapaian hasil belajar peserta didik yang lebih baik. Salah satu faktor yang menentukan berhasil atau tidaknya seseorang dalam belajar adalah faktor yang berasal dari dalam diri orang yang belajar (internal) bahwa hasil belajar dipengaruhi oleh faktor internal: tujuan, minat belajar, aktivitas, kecakapan, kebiasaan belajar, serta penguasaan bahan mata pelajaran.

Setelah dilakukan refleksi kegiatan pada siklus satu, maka dilakukan beberapa perbaikan kegiatan yang dianggap perlu demi meningkatkan motivasi dan hasil belajar peserta didik dengan mendesain pembelajaran berbasiskan bahan ajar berbasis media audio visual (Power Point). Pada siklus dua. Pada siklus dua selama kegiatan berlangsung, terlihat bahwa peserta didik sudah termotivasi untuk mengikuti pelajaran disebabkan adanya keberanian untuk mengemukakan pendapat dan adanya tugas yang diberikan pada setiap pertemuan. Peserta didik diharapkan memperlihatkan sejauh mana penguasaan materi yang telah diajarkan. Namun pada akhir siklus ini peserta didik sudah memperlihatkan aktivitas yang cukup baik dalam belajar. Seperti peserta didik sebagian besar memperhatikan pelajaran, berani bertanya kepada guru, berani mengemukakan pendapat. Hal ini berarti kualitas belajar sudah ada peningkatan.

Berdasarkan hasil perhitungan nilai hasil belajar peserta didik, terlihat bahwa pada tes awal, persentase ketuntasan secara klasikal peserta didik ialah 35\% dengan kategori sangat kurang. Setelah dilakukan tindakan pada siklus I adalah $64,76 \%$ dan meningkat menjadi $91,17 \%$ siklus II yang artinya berada pada kategori sangat tinggi.

Hal ini menunjukkan bahwa desain bahan ajar berbasis audio visual (Power Point) yang digunakan oleh guru meningkatan hasil belajar peserta didik kelas VIII-J SMPN 1 Tasikmalaya disebabkan karena pada siklus II, peran aktif peserta didik lebih ditingkatkan dengan cara mendorong peserta didik untuk aktif bertanya serta memberi kesempatan yang sama bagi setiap peserta didik untuk berpartisipasi dalam kegiatan pembelajaran. Selain itu, pengajar terlebih dahulu menginformasikan kepada peserta didik tentang hasil ujian mereka kemudian memperjelas tujuan dan manfaat pengetahuan yang diperoleh peserta didik selama 
pembelajaran serta menghubungkan topik yang akan diajarkan dengan topik yang telah dibahas sebelumnya.

Pembelajaran interaktif dengan bantuan presentasi Microsoft PowerPoint dapat meningkatkan pemahaman materi peserta didik. Karena dengan tampilan-tampilan atau ikonikon yang dimanfaatkan di dalam Microsoft PowerPoint dapat memotivasi peserta didik untuk memperhatikan materi yang sedang disampaikan sehingga apa yang di terangkan oleh guru dapat dimengerti oleh peserta didik. Hal tersebut sejalan dengan pendapat Hamalik (2008:11) menyebutkan bahwa "Jenis teknologi yang digunakan dalam pengajaran terdiri dari media audio visual (film, filmstrip, televisi, kaset dan video) dan komputer yang memiliki peran utama untuk memproses informasi secara cermat, cepat dengan hasil yang akurat. Sebagai sebuah media pembelajaran yang dapat meningkatkan minat dan perhatian peserta didik terhadap mata pelajaran tertentu".

Berdasarkan hasil pengamatan aktivitas belajar peserta didik selama proses pembelajaran terlihat adanya perubahan aktivitas belajar peserta didik dari siklus I ke siklus II. Hal ini ditandai dengan meningkatnya peran aktif peserta didik selama proses pembelajaran dan menurunnya persentase peserta didik yang melakukan kegiatan lain selama proses belajar mengajar berlangsung. Dari hasil pengamatan observer di siklus I, diperoleh data bahwa ada beberapa peserta didik yang tidak memperhatikan materi ajar yang disampaikan guru yang menggunakan Power Point. Hal ini disebabkan karena peserta didik tersebut hanya bercerita dan melakukan kegiatan yang lain seperti mengerjakan pekerjaan rumah untuk mata pelajaran lain. Namun setelah dilakukan refleksi, pada siklus II diperoleh data pengamatan bahwa anak tersebut telah memperhatikan materi ajar melalui penjelasan guru. Refleksi yang dilakukan adalah memberikan pengertian, penjelasan dan arahan untuk mengerjakan tugas, memberikan pernyataan ringan tentang materi pelajaran, serta menggali pengalaman awal peserta didik sebelum memasuki materi pelajaran. Perbaikan aktivitas tersebut terlihat bahwa pada semua pertemuan di siklus II di mana $100 \%$ peserta didik telah beraktivitas sesuai indikator pengamatan guru.

Terjadinya peningkatan persentase aktivitas peserta didik dari siklus I ke siklus II menunjukkan bahwa sebagian besar peserta didik memiliki perhatian yang besar dalam belajar PABP khususnya dalam pembelajaran pokok bahasan shalat sunah munfarid dan berjamaah yang menggunakan bahan ajar berbasis audio visual (Power Point). Peningkatan jumlah peserta didik yang bertanya serta menjawab pertanyaan menunjukkan keinginan peserta didik untuk lebih memahami materi pelajaran dan memecahkan permasalahan yang mereka hadapi serta menunjukkan keberanian mereka untuk bertanya yang patut untuk dihargai. Penggunaan bahan ajar berbasis media audio visual (Power Point), dapat meningkatkan aktivitas belajar peserta didikpun akan tinggi yang tentunya diharapkan dapat berdampak pada peningkatan hasil belajar peserta didik.

\section{KESIMPULAN}

Berdasarkan hasil penelitian maka dapat disimpulkan bahwa desain Pembelajaran berbasis bahan ajar berbasis media audio visual (Power Point) layak digunakan dalam pembelajaran dan dapat meningkatkan kualitas hasil belajar PABP peserta didik SMPN 1 Tasikmalaya pada materi shalat sunah munfarid dan berjamaah dengan kategori sangat baik. Karena ada peningkatan motivasi dan hasil belajar peserta didik dalam pelajaran PABP. Hal ini dapat dilihat dari peningkatan persentase nilai peserta didik sebelum dan sesudah diterapkan bahan ajar berbasis media audio visual (Power Point).

\section{DAFTAR PUSTAKA}

Asrial, dkk. (2020). Ethnoconstructivism E-Module to Improve Perception, Interest, And Motivation of Students in Class V Elementary School. Jurnal Pendidikan Indonesia, 9(1), 30-41. https://doi.org/10.23887/jpiundiksha.v9i1.19222

Hamalik, Oemar. (2008). Kurikulum dan Pembelajaran. Jakarta: Bumi Aksara. 
Hendra Pratama. (2016), Revitalisasi Pengembangan Bahan Ajar Geografi. Jurnal Pedagogy.

Prastowo Andi. (2014). Panduan Kreatif Membuat Bahan Ajar Inovatif. Yogyakarta: Diva Perss.

Pratama, \& Dkk. (2017). Pengembangan Multimedia Interaktif Berbasis Model Vak Pada Mata Pelajaran IPA Siswa Kelas V Di Sdn 2 Banjar Bali. Jurnal Edutech Undiksha, 5(1), $132-141$.

Subyantoro. (2007). Penelitian Tindakan Kelas. Semarang: Rumah Indonesia.

Sukiyasa, K., \& Sukoco, S. (2013). Pengaruh media animasi terhadap hasil belajar dan motivasi belajar siswa materi sistem kelistrikan otomotif. Jurnal Pendidikan Vokasi.

Undang-Undang Republik Indonesia Nomor 20 Tahun 2003, Sistem Pendidikan Nasional. 